\title{
The United States-Backed Containment of Turkey in the Eastern Mediterranean
}

\author{
ÇAĞATAY ÖZDEMIR \\ Researcher, Turkey \\ ORCID No: 0000-0001-9477-9761
}

ABSTRACT International competition over natural gas and oil has been escalating in the Eastern Mediterranean in recent years, and the region has become much more significant for many regional and global actors. This article claims that a bloc of regional actors, supported by the United States, has been following a containment policy against Turkey in the Eastern Mediterranean. By examining recent trends and developments with special focus on the policies directed against Turkey's rights and interests in the Eastern Mediterranean, this article demonstrates how Turkey is being isolated in the region, and discusses Turkey's reactions to its on-going containment.

Keywords: Energy, Eastern Mediterranean, Turkey, United States, Israel, Egypt, Greece, Cyprus 


\section{Introduction}

n recent years, the Eastern Mediterranean has increasingly become an economically dynamic and politically significant region due to its potential as a source of oil and natural gas. Due to its geo-strategic significance and location at the junction of Europe, Asia, and Africa, many countries may lay claim to the resources found in the region. In recent years, the question of oil and gas rights in the Eastern Mediterranean has become an even bigger issue, and now more actors feel that they have a stake in the region.

In 2019, the issue of the Eastern Mediterranean took on global importance and the question of where this will all lead ignited the interests of several actors. The Eastern Mediterranean is turning into a colossal 'laboratory' where the balance of power policies of strong global actors and regional states are being tested. ${ }^{1}$ Turkey, as a rising power, is a significant actor in the region and its

\section{Turkey, as a rising power, is a significant actor in the region and its geostrategic position and assertive foreign policy have attracted the attention of both global and regional actors}

geostrategic position and assertive foreign policy have attracted the attention of both global and regional actors. As a result of these changes, power struggles have come to the fore in the region.

The current literature regarding Eastern Mediterranean energy geopolitics does not sufficiently take into account Turkey's position in the equation. Much of the existing literature takes the policies of other regional actors, including Greece, Israel, and the Greek Cypriot Administration of South Cyprus (GCASC), as granted rather than addressing the complex nature of the issue along with its many layers. This article aims to expand on the existing literature regarding how intergovernmental cooperation may lead to the strategic exclusion of other governments. More specifically this article focuses on how the U.S. is trying to contain Turkey's action in the Eastern Mediterranean.

Even if containment may no longer be an explicit foreign policy strategy except in sanctions, it does come about in policy and alliance making in an implicit manner. As a specific policy generally associated with Realpolitik, containment was typically used as a strategy implemented by the United States (U.S.) during the Cold War era to prevent the Soviet expansion. ${ }^{2}$ Although it existed as an American foreign policy strategy far earlier, the concept of containment first appeared in the correspondences of George Kennan, a U.S. diplomat seen now in history as a Soviet expert. In an anonymous article published in Foreign Affairs, Kennan defended the idea that the Soviet Union was a danger to the U.S. and needed to be addressed with a long-term strategy that would lessen its 
stronghold on Eastern Europe. ${ }^{3}$ The most prominent examples of this policy in action would be the Truman Doctrine and the Marshall Plan, as well as the act of cutting off supplies to Soviet-occupied East Germany. ${ }^{4}$

The U.S. containment policy was not only exercised against the Soviet Union. Indeed, the diplomatic intervention of sanctions as a containment policy never lost its appeal for the U.S. even after the Cold War. In the post-Cold War era, the Clinton Administration implemented a 'dual containment' policy to address Iran and Iraq. ${ }^{5}$ In 1993, the Clinton Administration, rather than using Iran and Iraq against each other, followed a policy of containing them both at the same time. ${ }^{6}$ Looking at the patterns within U.S. foreign policy, it is arguable that the premise of containment still remains, and its implementation is becoming even more aggressive in that it is being increasingly reliant on military reinforcements. Containment has not left the U.S. foreign policy rhetoric, either. In the early 2010s, at the time when John Mearsheimer wrote his introduction to the sixtieth-anniversary edition of Kennan's book, American analysts were debating how the U.S. should go about dealing with China. ${ }^{7}$

Today it is possible to argue that Turkey faces an American containment policy that attempts to undermine its power in the Eastern Mediterranean and change the strategic balances in the region. An alliance between regional actors and the United States, supported by other Western countries, has been emerging as a means to contain Turkey's role and influence in the region. The main sources of motivation behind this containment effort are geopolitics and energy. While the hydrocarbon discoveries in the region could support the economic development of countries, it could also have a game-changing effect in the region. Hence, for regional players like Israel, Egypt, and Greece, on the one hand, and the U.S., on the other, forming an alliance, which would lead to the isolation of Turkey a in the Eastern Mediterranean, has become a mutually acceptable strategy.

This article offers an analysis of the developments that demonstrate how Turkey is being contained in the Eastern Mediterranean. It will first discuss the policies of the United States and its regional allies in the Eastern Mediterranean that isolate Turkey and ignore its sovereign rights, as well as those of Turkish Cypriots. It will then offer some predictions as to how Turkey will respond to the containment and defend its rights and interests

\section{Turkey versus the United States in the Eastern Mediterranean}

Thanks to its democratic regime and assertive foreign policy, Turkey is a powerful regional actor and has been a source of inspiration for other countries in the region with its economy, strong army, and geopolitical role. Since it 
Israel is aiming to bypass

Turkey through the EastMed

project, thus disregarding

both Turkey's and the Turkish

Cypriots' inalienable rights

over Eastern Mediterranean

resources

possesses the potential to be a regional great power, Turkey has been experiencing both military and diplomatic containment efforts by regional and global actors to keep its actions in check. Recent developments show that a distinct type of containment against Turkey is being enacted by the United States in the Eastern Mediterranean, which has become much more important for the U.S. in recent years due to its strategic geographical location and potential as a source of oil and natural gas. ${ }^{8}$ The U.S. has been exercising the containment policy through its regional allies and proxies.

The Eastern Mediterranean is a region that exemplifies the efforts to change the balance of power by reopening concerns about stability along new fault lines of competition. ${ }^{9}$ Understanding balance of power politics in the Eastern Mediterranean requires analyzing inter-state relations that are motivated by foreign policy interests and national security. ${ }^{10}$

Countries that have common maritime borders are expected to make agreements on the limits of their zones of authority such as Exclusive Economic Zone (EEZ) and continental shelf. However, without taking the consent of Turkey or Turkish Cypriots, the GCASC is unilaterally implementing drilling activities and seismic explorations and thus increasing tension in the region. ${ }^{11}$ Although the two communities in Cyprus should possess equal rights under international law to utilize the hydrocarbon resources around the island, the GCASC has, without the consent of the Turkish Cypriots, concluded bilateral agreements with Egypt and Israel regarding the delimitation of Exclusive Economic Zone (EEZ) and called upon international companies to conduct hydrocarbon research within its EEZ. ${ }^{12}$ Furthermore, a portion of the EEZ claimed by the GCASC overlaps with Turkey's continental shelf. It is within such an atmosphere that Turkey is faced with containment by an anti-Turkish bloc isolating Turkey and preventing it from taking appropriate actions to protect its interests.

The region is vital for Turkey in terms of the inalienable rights of the Turkish Cypriots as well as its own natural resources and national security. According to the Turkish Statistical Institute, Turkey spent approximately $\$ 41$ billion for energy imports in $2019 .{ }^{13}$ In order to curtail its dependency on foreign markets for its energy supply, Turkey needs to develop its own resources. The Eastern Mediterranean is a geo-strategically significant area for Turkey in terms of natural resources that could contribute to its economy. Furthermore, Turkey's 


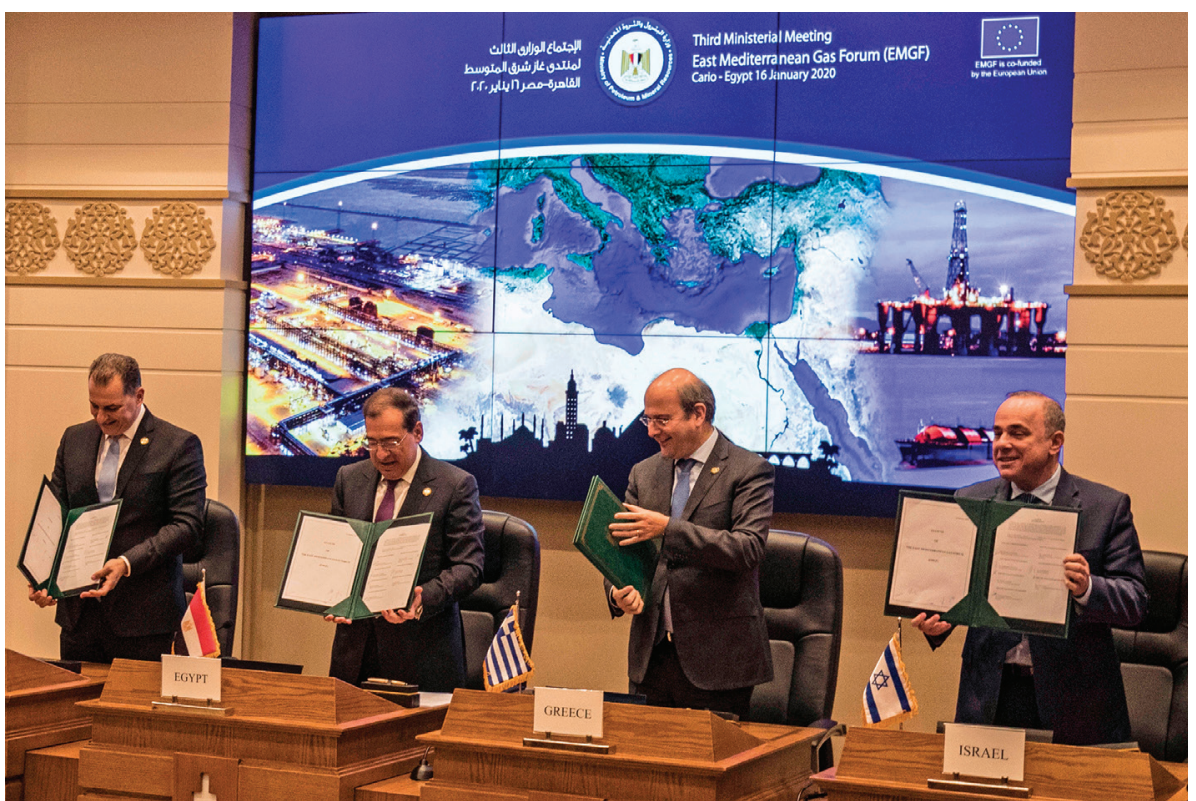

geographic location makes it the best route for the transportation of Eastern Mediterranean gas to European markets. Ankara already possesses established pipeline projects that are well integrated with European markets. ${ }^{14}$ However, as part of the containment policy being leveraged against Turkey, Greece, Egypt, and Israel aim to prevent Turkey from assuming a role in the energy sector. ${ }^{15}$

Turkey, to defend its rights over its zones of sovereignty and the rights of the Turkish Cypriots, is currently carrying out hydrocarbon exploration with its drilling vessels Fatih and Yavuz, along with the country's two other seismic vessels, Oruç Reis and Barbaros Hayrettin Paşa. ${ }^{16}$ Although Turkey is operating within its continental shelf and exercising its legal rights to drill, Greece and the GCASC have declared Turkey's activities in the Eastern Mediterranean illegal and urged Turkey to "withdraw all its drilling and seismic vessels" from the region. ${ }^{17}$

Due to its significant geo-strategic position in the region, Turkey is subject to confrontation from a Western bloc composed of Western powers and their regional partners Israel, Egypt, the GCASC, and Greece. ${ }^{18}$ This anti-Turkish bloc aims to prevent Turkey from exercising its legal rights and seeks to keep Turkey out of the Eastern Mediterranean. The military exercises held by Egypt and backed by the GCASC, Greece, and Israel can be mentioned as an example. ${ }^{19}$ In this regard, it can be said that the bloc considers power relations in the Eastern Mediterranean a zero-sum game, in which what is beneficial for Turkey is harmful for them.
Israeli Minister of Energy Steinitz (R), Greek Minister of Energy Hatzidakis ( $\left.2^{\text {nd }}-R\right)$, Egyptian Minister of Petroleum el-Molla ( $2^{\text {nd }}-\mathrm{L}$ ) and Greek Administration of Southern Cyprus Minister of Energy Lakkotrypis (L) attend the East Mediterranean Gas Forum in Cairo, on January 16, 2020. 


\section{By utilizing both domestic political tools and the support of international organizations, Greece has sought to delegitimize Turkish concerns and perceived threats by invoking and utilizing Islamophobic sentiments on a global scale}

A recent example of regional powers acting collectively against Turkey for geopolitical reasons in the Eastern Mediterranean occurred on November 5, 2019 in Athens. In parallel with the military exercise, the Defense Ministers of Egypt, the GCASC, and Greece signed a joint document "condemning Turkey's activities in the Eastern Mediterranean." ${ }^{20}$ According to the document, the three ministers reached an agreement to engage in joint military exercises and expand defense cooperation in various fields such as cyber security and crisis management. ${ }^{21}$ At the end of the trilateral meeting, Greek Defense Minister Savvas Angelidis claimed at a news conference that the three actors criticize Turkey's "provocative actions" in the region. Egyptian Defense Minister Mohamed Zaki also stated that the three countries need to maintain cooperation to engage with the challenges and protect their common interests against Turkey's actions. ${ }^{22}$

The efforts of the regional powers to contain Turkey are backed mainly by the United States, who has a longstanding and multifaceted presence in. Recent hydrocarbon discoveries have made the region much more significant for Washington in terms of the supply of energy resources. Other main impetuses behind the U.S. interest in the region are based on the region's relevance for European security and its geo-strategic significance as a route to other critical regions and as a prospective center of crises and flashpoints. ${ }^{23}$ The U.S. regards the establishment of a reliable system of energy transportation to its allies as integral to strengthening security. ${ }^{24}$ It has increased its engagement in the region via international oil and gas exploration companies such as Noble Energy and ExxonMobil and by making an alliance with Israel and the GCASC. ${ }^{25}$ Moreover, in order to prevent European dependence on Russia for energy supply, it strategically aims to transfer energy resources from the Eastern Mediterranean to Europe.

In the Eastern Mediterranean the U.S. cooperates with Israel, Egypt, Greece, and the GCASC at the expense of Turkey. During recent years it has shown special attention in cooperating with Greece and the GSASC. Although, during his visit he met with both leaders in the neutral zone, for the first time in history, and attempted to reconcile them, when the then U.S. Vice President Joe Biden visited Cyprus in 2014, he emphasized that the GCASC was an important partner to the U.S. and a key player in the Eastern Mediterranean. ${ }^{26}$ The U.S. has been using NATO naval base on Crete, less than 500 miles from Cyprus. Washington has further improved its security cooperation through the initiation of a U.S.-Greece strategic dialogue on December 13, 2018. ${ }^{27}$ 
As part of the U.S. containment policy against Turkey, on April 9, 2019, U.S. Senators Bob Menendez (D-New Jersey), ranking Member of the Senate Foreign Relations Committee, and Marco Rubio (R-Florida) introduced bipartisan legislation that undermines Turkey's interest in the Eastern Mediterranean. ${ }^{28}$ The bill, which passed the Senate Foreign Relations Committee on June 25, 2019, mainly aims to support cooperation between Greece, the GCASC, and Israel by strengthening their partnership in energy and security. Accordingly, the Eastern Mediterranean Security and Energy Partnership Act of 2019 includes:

Lifting the prohibition on arms sales to the Republic of Cyprus; authorizing the establishment of a United States-Eastern Mediterranean Energy Center to facilitate energy cooperation between the U.S., Israel, Greece, and Cyprus; authorizing $\$ 3,000,000$ in Foreign Military Financing (FMF) assistance for Greece; authorizing \$2,000,000 for International Military Education and Training (IMET) assistance for Greece and \$2,000,000 for Cyprus; impeding the transfer of F-35 aircraft to Turkey, as long as Turkey continues with plans to purchase the S-400 air defense system from the Russian Federation, a purchase that would be sanctionable under U.S. law; requiring the Administration to submit to Congress a strategy on enhanced security and energy cooperation with countries in the Eastern Mediterranean, as well as reports on malign activities by Russia and other countries in the region. ${ }^{29}$

The bill aims to reshape U.S. policy in the Eastern Mediterranean by ending three decades of U.S. arms embargo on the GCASC. With the introduction of the bill, the U.S. intends to decrease Europe's dependence on Russian energy and forming new alliances in the Eastern Mediterranean. Another implication of the bill is that Washington clearly neglects the maritime jurisdiction of Turkey and the Turkish Republic of Northern Cyprus (TRNC). On the contrary, it promotes the on-going seismic survey and gas drilling activities of international companies on behalf of the GCASC. ${ }^{30}$ In addition, the bill implies support for the EastMed project, which bypasses Turkey and disregards both Turkey's and the Turkish Cypriots' inalienable rights around the island of Cyprus. Altogether, the above-mentioned developments indicate U.S. backing for Greece and the GCASC, and the perpetuation of Washington's containment policy against Turkey, which seeks to undermine Turkey's rights and interests in the Eastern Mediterranean.

\section{Regional Partners of the United States}

This article argues that the United States is implementing a containment policy against Turkey by means of regional partnerships. In other words, in the name of addressing military and diplomatic challenges, a U.S.-guided strate- 


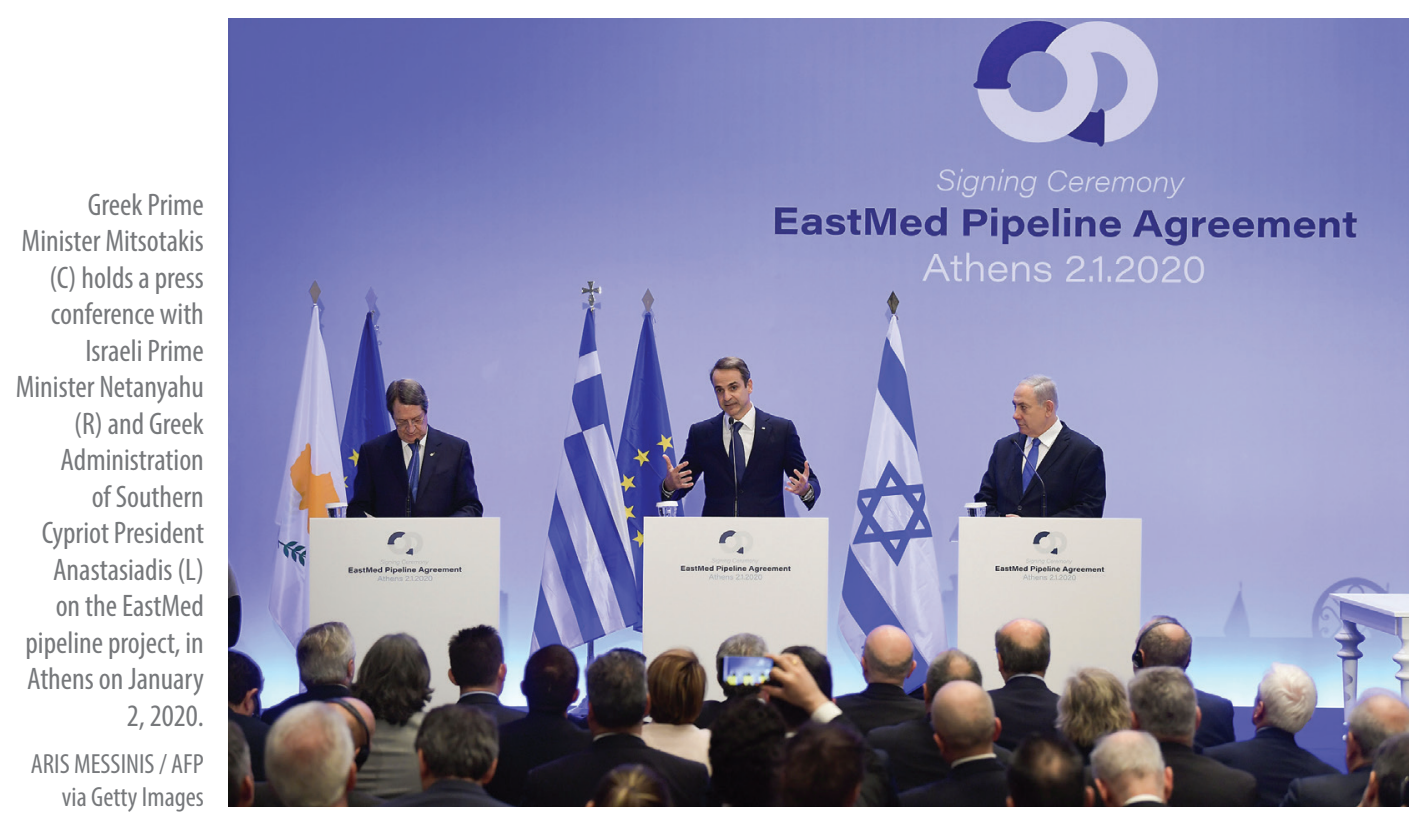

gic alliance against Turkey has been formed in the region. With various calculations the U.S., together with its allies in the region, is confronting Turkey in different policy areas and attempting to marginalize Turkey's position in the Eastern Mediterranean. In this section, the positions of the regional partners of the United States in the Eastern Mediterranean against Turkey will be discussed.

\section{Israel}

Israel has been supported by the United States in its opposition to Turkey's interests in the region. Since 2009, discoveries in the Tamar and Leviathan gas fields under Israel-U.S. cooperation have spurred the exploration of resources in the Eastern Mediterranean. ${ }^{31}$ Israel, the first country in the region to explore for gas, initiated a strategic partnership with Greece and the GCASC, which became more significant after the deterioration of its political relations with Turkey due to the Mavi Marmara incident in 2010. ${ }^{32}$ The EastMed Pipeline Project, which would carry Israeli and Cypriot gas into Europe via Greece, is politically motivated and supported by the European Union and the U.S.. ${ }^{33} \mathrm{Al}$ though the projected $\$ 6$ billion cost of the EastMed project is too high, Israel, Greece, and the GCASC still regards it as a viable option. ${ }^{34}$

Although transporting the gas via Turkey is the most practical and less costly option to bring Eastern Mediterranean gas into Europe, this scenario is currently unfeasible due to the existing disputes between Israel and Turkey, and Israel's main goal of getting U.S. support. Israel has long viewed Turkey's insis- 
tence on Palestine's sovereignty negatively, and even labelled Turkey's position as "anti-Semitic." ${ }^{35}$ Turkey, on the other hand, sees Israel's close partnership with the U.S., specifically its lobbying power, as a threat to the stability of the Middle East and North Africa (MENA). Due to the negative consequences of U.S. foreign policy in MENA after 9/11 and the subsequent Iraq war, ${ }^{36}$ Turkey has called for less external intervention in regional politics and the empowerment of regional actors to make their

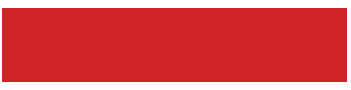

\section{The EU has explicitly supported the EastMed pipeline project against Turkey's interests} own decisions. However, Israel's accusations that Turkey, along with Iran, aided Hamas against the safety and well-being of the Jewish people, has made it difficult for the two countries to cooperate. ${ }^{37}$ Consequently, as part of a containment policy against Turkey, Israel is aiming to bypass Turkey through the EastMed project, thus disregarding both Turkey's and the Turkish Cypriots' inalienable rights over Eastern Mediterranean resources.

\section{Egypt}

Egypt arguably remains one of the most complicated cases in Turkish foreign policy and its goals in the Eastern Mediterranean region. Turkey has opposed the overthrow of Egypt's elected President Mohammed Morsi by a military coup headed by General Abdel Fattah el-Sisi in 2013. When Turkey began to suspect that those working closely with the U.S. wished to bring down the elected president, it became a personal mission of the Presidency to ensure that democratic sovereignty is respected in the Middle East. On the other hand, Turkey's granting of asylum to exiled Muslim Brotherhood members was interpreted as an act of aggression by the Sisi Administration. The death of Morsi in the courtroom (as a result of prior altercations in prison) has added tension and led to calls for an investigation on the international stage.

In 2003, Egypt had signed an agreement with the GCASC delimit their zones of maritime jurisdiction. In 2014, Egypt organized a meeting with Greece and the GCASC, openly excluding Turkey, to draw the maritime borders in the Eastern Mediterranean and to discuss the use of hydrocarbon resources. In addition, Egypt signed a Memorandum of Understanding with the GCASC in February 2015 to construct a pipeline connecting Egypt's liquid natural gas (LNG) infrastructure with the Aphrodite gas field in the south of Cyprus. ${ }^{38}$ On January 14, 2019, Egypt hosted the Eastern Mediterranean Gas Forum (EMGF), which also excluded Turkey and the TRNC. ${ }^{39}$ This forum formalized developing energy ties between a number of regional actors, including the Egypt, Greece, Italy, Israel, GCASC, and Jordan. ${ }^{40}$ The stated aim of this forum is to share and utilize the oil and gas in the Eastern Mediterranean in the most efficient way, and to establish a regional gas market that would fulfill the interests of its members 
The Council of the European Union immediately expressed its serious concerns over Turkey's drilling activities in the Eastern Mediterranean and argued that these actions would negatively affect the Turkey-EU relationship through the maintenance of security and supply-demand balance. ${ }^{41}$ However, the absence of other littoral states like Turkey, the TRNC, Lebanon, and Libya, illustrates that the forum was not inclusive to all actors in the Eastern Mediterranean. When all of these developments are analyzed collectively, they point to a containment policy aiming to marginalize and weaken Turkey's position in the region.

\section{Greece}

Turkey' disagreement with Greece regarding Cyprus is considered a longterm dispute. Greece has been encouraging Turkey's exclusion from the Eastern Mediterranean and urging regional actors such as Israel, Egypt, and the GCASC against Turkey. The EMGF is a relevant example. Turkey's exclusion remains a major stumbling block for the future of energy cooperation in the region. Incorporating Turkey into the forum would improve its prospects of success. Conversely, Turkey's exclusion from the EMGF indicates the instability of the Eastern Mediterranean region because regional sovereignty is being ignored. Turkey's exclusion remains a major stumbling block to the future of energy cooperation in the region. Turkish media organizations have stated that the purpose of Turkey's ongoing explorations are is to send a message to the EMGF regarding its exclusion. In recent years Greece has also been seeking to garner support from the EU against Turkey's gas exploration activities in the Eastern Mediterranean. ${ }^{42}$ As will be mentioned below, Greece's complaints led the EU to decide on some diplomatic and economic decisions against Turkey.

Furthermore, Greece's liaising with the Greek Cypriot disregards Turkey's sovereign rights to the continental shelf and the EEZ. The issuance of an arrest warrant for Turkish drillship personnel is a significant case. On June 10, 2019, in order to stop Turkey's exploration activities, the Greek Cypriot Administration issued an international arrest warrant for 25 people, including personnel of the Turkish drillship Fatih and officials from companies cooperating with TPAO. $^{43}$

Efforts to initiate enosis have been exerted since the time of the Ottoman Empire, and Turkey has been aware since the beginning that Greece is only interested in developing Southern Cyprus. The current situation is not the only instance in which Greece has attempted to block Turkish efforts to ameliorate the plight of the Turkish Cypriots. Throughout the history of Cyprus, Greece has attempted to contain Turkey's actions in the region. By utilizing both do- 
mestic political tools and the support of international organizations, Greece has sought to delegitimize Turkish concerns and perceived threats by invoking and utilizing Islamophobic sentiments on a global scale. It should be clear that Turkey recognizes the Turkish Cypriots as a sovereign and culturally unique community, unlike Greece's approach to the Greek Cypriots, which has since the beginning advocated for unification with their perceived homeland.

\section{The European Union}

In 2004, the EU accepted the GCASC as a full member even though the Cyprus issue was not resolved and Turkish Cypriots were not represented in the government and administration. ${ }^{44}$ Due to Turkey's refusal to apply the Additional Protocol of the Ankara Association Agreement to the GCASC, which Turkey does not recognize, the EU has blocked the accession negotiations with Turkey since 2006. Recently, the EU has explicitly supported the EastMed pipeline project against Turkey's interests. ${ }^{45}$

The EU's open support to Greek and Greek Cypriot positions in the Eastern Mediterranean contributes to Turkey's isolation in the Eastern Mediterranean. The EU has been warning Ankara since 2018 to cease its drilling activities in the maritime zones claimed by Greece and the GCASC. ${ }^{46}$ On May 3, 2019, when Turkey announced through the international maritime navigational telex system that it would engage in drilling activities off the southern coast of Cyprus, it received negative reactions from the EU. ${ }^{47}$ The EU's foreign affairs commissioner Federica Mogherini stated that Turkey should respect the sovereign rights of Cyprus and avoid any kind of illegal action. ${ }^{48}$ When Turkey continued to explore natural gas in its continental shelf, as well as in the TRNC's zones of authority, Greece and the GCASC called upon the EU to implement punitive measures against Turkey on June 18, 2019. ${ }^{49}$ The Council of the European Union immediately expressed its serious concerns over Turkey's drilling activities in the Eastern Mediterranean and argued that these actions would negatively affect the Turkey-EU relationship. ${ }^{50}$ On July 15, 2019, the EU decided to impose sanctions on Turkey with the following statement:

In light of Turkey's continued and new illegal drilling activities, the Council decides to suspend negotiations on the Comprehensive Air Transport Agreement and agrees not to hold the Association Council and further meetings of the EU-Turkey high-level dialogues for the time being. The Council endorses the Commission's proposal to reduce the pre-accession assistance to Turkey for 2020 and invites the European Investment Bank to review its lending activities in Turkey, notably with regard to sovereign-backed lending. ${ }^{51}$

Evidently the EU stands by Greece and the GCASC and seeks to impede Turkey from exercising its legal rights in the Eastern Mediterranean. The EU's 
international politics as a zero-sum game and regards containment as a political strategy to prevent the expansive tendencies of one state against the others. Hence, for states access to energy resources can be a national security issue, which can lead them to form new alliances and implement a containment policy against competing actors. The anti-Turkish bloc views Turkey's efforts in the Eastern Mediterranean as a potential threat to their national interests. Given a zero-sum scenario in which Turkey increases its power within the region, the United States and its regional partners think that they will unable to benefit from the energy resources.

Turkey's recent policies in the Eastern Mediterranean should be considered as reactions arising from its understanding of the escalating containment policy being exercised by regional and global actors that have both economic and security interests in the region. ${ }^{52}$ Notwithstanding the degree of containment it faces, Turkey is expected to continue to defend its rights as well as those of the Turkish Cypriots. Accordingly, Turkey will likely continue hydrocarbon explorations through its vessels and maintain its presence in the region militarily, economically, and politically. In that regard, the containment will not likely push Turkey into a more passive position but to take more proactive measures to counter it.

Considering that it has not resulted in a change of Turkey's polices and something like that is not expected in the years to come, the U.S.-backed containment efforts against Turkey are not effective. Turkey has started to follow a more autonomous foreign policy in the Eastern Mediterranean region. Lastly, on the one hand, Turkey will continue to protect both its own sovereign rights and those of the Turkish Cypriots. On the other hand, it will continue to oppose any unilateral action in the region and to abide by the principles of international law.

\section{Endnotes}

1. Aristotle Tziampiris, "The New Eastern Mediterranean as a Regional Subsystem," in Spyridon N. Litsas and Aristotle Tziampiris (eds.), The New Eastern Mediterranean: Theory, Politics and States in a Volatile Era, (Cham: Springer International Publishing, 2019), p. 25.

2. John Lewis Gaddis, Strategies of Containment: A Critical Appraisal of Postwar American National Security Policy, (New York: Oxford University Press, 1982), p. 4. 
3. George F. Kennan, "The Sources of the Soviet Conduct," Foreign Affairs, Vol. 25, No. 4 (July 1947), retrieved September 5, 2019 from https://www.foreignaffairs.com/articles/russian-federation/1947-07-01/ sources-soviet-conduct.

4. John J. Mearsheimer, "Introduction" in George F. Kennan, American Diplomacy, (Chicago: The University of Chicago Press, 2012), p. vii.

5. James D. Boys, Clinton's Grand Strategy: US Foreign Policy in a Post-Cold War World, (New York, NY: Bloomsbury Academic, 2015), p. 62.

6. Boys, Clinton's Grand Strategy, p. 62.

7. Mearsheimer, "Introduction," p. vii.

8. Andrea Prontera and Mariusz Ruszel, "Energy Security in the Eastern Mediterranean," Middle East Policy, Vol. 24, No. 3 (2017), p. 145.

9. Moshe Ma'oz, "The Arab Spring and the New Geo-Strategic Environment in the Middle East," Insight Turkey, (October 1, 2012), retrieved July 14, 2019, from https://www.insightturkey.com/commentaries/ the-arab-spring-and-the-new-geo-strategic-environment-in-the-middle-east.

10. Prontera and Ruszel, “Energy Security in the Eastern Mediterranean," p. 145.

11. "Cyprus," Republic of Turkey-Ministry of Foreign Affairs.

12. Nurşin Ateşoğlu Güney, "New Balance of Power in the Eastern Mediterranean and Turkey," Center for Strategic Research, No. 17 (June 2019), p. 6, retrieved July 14, 2019, from http://sam.gov.tr/wp-content/ uploads/2019/06/SAM-Papers-No.-17.pdf.

13. Gökçe Topbaş, "Enerji İthalatı Faturası 2019'da Yüzde 4,2 Azaldı,” Anadolu Ajansı, (February 6, 2020), retrieved June 2, 2020 from https://www.aa.com.tr/tr/ekonomi/enerji-ithalati-faturasi-2019da-yuzde-42-azaldi/1726127.

14. Soner Kıstak, "Eastern Mediterranean Gas: Why Turkey Is the Key to Its Success," Hürriyet Daily News, (November 14, 2019), retrieved November 15, 2019, from http://www.hurriyetdailynews.com/easternmediterranean-gas-why-turkey-is-key-to-its-success-148668.

15. İsmail Numan Telci, "Why the Eastern Mediterranean Is of Strategic Importance for Turkey," The New Turkey, (May 13, 2019), retrieved November 16, 2019, from https://thenewturkey.org/why-the-eastern-mediterranean-is-of-strategic-importance-for-turkey.

16. "Turkey Accelerates Exploration in Eastern Mediterranean," Daily Sabah, (September 6, 2019), retrieved November 15, 2019, from https://www.dailysabah.com/energy/2019/09/06/turkey-acceleratesexploration-in-eastern-mediterranean.

17. "Cyprus cüCalls Turkey Gas Exploration 'Provocative and Aggressive,'”Al Jazeera, (October 4, 2019), retrieved November 16, 2019, from https://www.aljazeera.com/news/2019/10/cyprus-calls-turkey-gasexploration-provocative-aggressive-191004062752503.html.

18. Telci, "Why the Eastern Mediterranean Is of Strategic Importance for Turkey."

19. Telci, "Why the Eastern Mediterranean Is of Strategic Importance for Turkey."

20. Menna A. Farouk, "Egypt Conducts Joint Drills with Greece, Cyprus amid Turkey Tensions," Al-Monitor, (November 18, 2019), retrieved November 20, 2019, from https://www.al-monitor.com/pulse/originals/2019/11/egypt-cyprus-greece-naval-drills-tension-turkey.html.

21. Farouk, "Egypt Conducts Joint Drills with Greece, Cyprus amid Turkey Tensions."

22. Farouk, "Egypt Conducts Joint Drills with Greece, Cyprus amid Turkey Tensions."

23. Ian O. Lesser, "The United States and the Future of Mediterranean Security: Reflections from GMF's Mediterranean Strategy Group," The German Marshall Fund of the United States, (April 2015), retrieved July 11, 2019, from http://www.gmfus.org/publications/united-states-and-future-mediterranean-security.

24. Shaffer, Energy Politics, p. 135. 
25. Matthew J. Bryza, "East Med Energy: Restoring Squandered Opportunities," Turkish Policy Quarterly, Vol. 17, No. 3 (November 2018), pp. 84-87.

26. Revecca Pedi and Ilias Kouskouvelis, "Cyprus in the Eastern Mediterranean: A Small State Seeking for Status," in Spyridon N. Litsas and Aristotle Tziampiris (eds.), The New Eastern Mediterranean: Theory, Politics and States in a Volatile Era, (Cham: Springer International Publishing, 2019), p.160.

27. Micha'el Tanchum, "A Dangerous Policy of Turkish Containment in the Eastern Mediterranean," The Turkey Analyst, (July 3, 2019), retrieved from https://www.turkeyanalyst.org/publications/turkey-analyst-articles/item/623-a-dangerous-policy-of-turkish-containment-in-the-eastern-mediterranean.html.

28. Eastern Mediterranean Security and Energy Partnership Act of 2019, United States Senate Committee on Foreign Relations, (April 9, 2019), retrieved July 09, 2019, from https://www.foreign.senate.gov/ press/ranking/release/menendez-rubio-introduce-eastern-mediterranean-security-and-energy-partnership-act-of-2019.

29. Eastern Mediterranean Security and Energy Partnership Act of 2019, United States Senate Committee on Foreign Relations.

30. Nurşin Ateşoğlu Güney, "An Iron Curtain on the Eastern Mediterranean: Will the US Isolate Turkey?," The New Turkey, (May 16, 2019) retrieved July 11, 2019, from https://thenewturkey.org/an-iron-curtainon-the-eastern-mediterranean-will-the-us-isolate-turkey.

31. Prontera and Ruszel, "Energy Security in the Eastern Mediterranean," p. 146.

32. Prontera and Ruszel, “Energy Security in the Eastern Mediterranean," p. 146.

33. Güney, "New Balance of Power in the Eastern Mediterranean and Turkey," p. 9.

34. "Eastmed Policy Brief," Eastern Mediterranean Regional Training Partnership, retrieved July 16, 2019, from https://eastmedproject.eu/files/IO6-1stpolicybrief.pdf.

35. Christos Kassimeris, "NATO and the Aegean Disputes," Defence and Security Analysis, Vol. 24, No. 2 (June, 2008), pp. 165-179.

36. Stephen Walt, "What Dennis Ross Gets Wrong About the 'Israel Lobby,"' Forward, (October 6, 2017), retrieved July 12, 2019, from https://forward.com/opinion/384492/what-dennis-ross-gets-wrongabout-the-israel-lobby/.

37. Israel Accuses Turkish PM of Inciting Anti-Semitism, Haaretz, (January 26, 2010), retrieved July 9 , 2019, from https://www.haaretz.com/1.5049419.

38. Prontera and Ruszel, "Energy Security in the Eastern Mediterranean," p. 150.

39. Tony Chavez, "Things Are About to Change: Oil and Gas Have Been Found in the Eastern Mediterranean," The National Interest, (March 10, 2019), retrieved July 11, 2019, fromhttps://nationalinterest.org/ blog/buzz/things-are-about-change-oil-and-gas-have-been-found-eastern-mediterranean-46557.

40. Keith Johnson, "Club Med: Israel, Egypt, and Others Form New Natural Gas Group," Foreign Policy, (January 15, 2019) retrieved July 16, 2019, from https://foreignpolicy.com/2019/01/15/club-med-israelegypt-and-others-form-new-natural-gas-group/.

41. "Egypt... A Regional Energy Center in the Eastern Mediterranean," State Information Service-Egypt, retrieved July 14, 2019, from http://www.sis.gov.eg/section/7302/8363?lang=en-us.

42. Ali Kucukgocmen, Michele Kambas, and Jonathan Spicer, "Greece, Cyprus Pressure EU to Act over Turkey Gas Drilling as Ankara Digs in," Reuters, (June 18, 2019), retrieved from https://www.reuters.com/ article/us-cyprus-turkey-ship/greece-cyprus-pressure-eu-to-act-over-turkey-gas-drilling-as-ankaradigs-in-idUSKCN1TJ1F0.

43. "Cyprus," European Union, retrieved September 6, 2019, from https://europa.eu/european-union/ about-eu/countries/member-countries/cyprus_en.

44. "European Neighbourhood Policy and Enlargement Negotiations: Turkey," European Union, retrieved from https://ec.europa.eu/neighbourhood-enlargement/countries/detailed-country-information/turkey_en. 
45. Güney, "New Balance of Power in the Eastern Mediterranean and Turkey," pp. 8-9.

46. "European Council Meeting (March 22, 2018)," European Council, (March 23, 2018), retrieved September 5, 2019, from https://www.consilium.europa.eu/media/33457/22-euco-final-conclusions-en. pdf.

47. Tanchum, "A Dangerous Policy of Turkish Containment in The Eastern Mediterranean."

48. "Statement by High Representative/Vice-President Federica Mogherini on Turkey's Intended Drilling Activities within the Exclusive Economic Zone of Cyprus," European External Action Service, (May 4, 2019), retrieved September 5, 2019, from https://eeas.europa.eu/headquarters/headquarters-homepage/61836/statement-high-representativevice-president-federica-mogherini-turkeys-intended-drilling_en.

49. Helena Smith, "Greece and Cyprus Call on EU to Punish Turkey in Drilling Dispute," The Guardian, (June 18, 2019), retrieved September 05, 2019, from https://www.theguardian.com/world/2019/jun/18/ greece-and-cyprus-call-on-eu-to-punish-turkey-in-drilling-dispute.

50. "Council Conclusions on Enlargement and Stabilization and Association Process," European Council, (June 18, 2019), retrieved September 6, 2019, from https://www.consilium.europa.eu/en/press/pressreleases/2019/06/18/council-conclusions-on-enlargement-and-stabilisation-and-association-process/.

51. "Turkish Drilling Activities in the Eastern Mediterranean: Council Adopts Conclusions," Council of the European Union, (July 15, 2019), retrieved September 6, 2019, from https://www.consilium.europa. eu/en/press/press-releases/2019/07/15/turkish-drilling-activities-in-the-eastern-mediterranean-council-adopts-conclusions/.

52. Tanchum, "A Dangerous Policy of Turkish Containment in the Eastern Mediterranean." 